\title{
Estradiol Rapidly Regulates Membrane Estrogen Receptor $\alpha$ Levels in Hypothalamic Neurons
}

\author{
Reymundo Dominguez and Paul Micevych \\ Laboratory of Neuroendocrinology of the Brain Research Institute and Department of Neurobiology, David Geffen School of Medicine at University of \\ California, Los Angeles, Los Angeles, California 90095-1763
}

\begin{abstract}
Estrogen receptors (ERs) and estrogen-binding proteins have been localized intracellularly and on the cell surface. The membraneassociated proteins initiate signaling that activates a myriad of cellular responses including the modulation of ion channels and ultimately transcription. Although many of the downstream actions of membrane ERs, including ER $\alpha$ and ER $\beta$, have been characterized, the mechanisms regulating membrane ER levels have remained elusive in the nervous system. In the present study, we used surface biotinylation to identify and study the estradiol regulation of membrane ER $\alpha$ in mixed-sex, cultured hypothalamic neurons from rat. Following surface biotinylation, Western blot analysis revealed full-length $66 \mathrm{kDa} \mathrm{ER} \alpha$ and several ER $\alpha$ splice variants, most notably a biotinylated $52 \mathrm{kDa} E R \alpha$-immunoreactive protein. Treatment of the neurons with estradiol caused a rapid and transient increase of the biotinylated $52 \mathrm{kDa}$ and $66 \mathrm{kDa}$ ER $\alpha$ proteins in the plasma membrane. Exposure of the neurons to estradiol also significantly increased internalization of $52 \mathrm{kDa}$ and $66 \mathrm{kDa} \mathrm{ER} \alpha$ membrane proteins, a measure of receptor activation. In the hypothalamus, membrane ER $\alpha$ signaling depends on transactivation of metabotropic glutamate receptor-1a (mGluR1a). Estradiol treatment increased the internalization of mGluR1a in parallel with $\mathrm{ER} \alpha$, a finding consistent with the hypothesis of an $\mathrm{ER} \alpha$-mGluR1a signaling unit. These results demonstrate that estradiol regulates the amount of $\mathrm{ER} \alpha$ in the membrane, suggesting estradiol can regulate its own membrane signaling.
\end{abstract}

\section{Introduction}

Estrogens are steroid hormones involved in sexual reproduction, neuroprotection, and learning and memory in the brain. Estradiol, the major estrogen, elicits its actions by binding and activating both intracellular estrogen receptors (ERs) and receptors associated with the plasma membrane. While the mechanisms of intracellular ER regulation and function have been largely elucidated, how levels of membrane-associated ER are regulated has remained more elusive (Levin, 2008).

Intracellular ERs, $\mathrm{ER} \alpha$ and $\mathrm{ER} \beta$, are ligand-induced transcription factors that modulate-specific gene expression, while membrane-associated ERs rapidly alter cellular physiology by activating G-protein-coupled receptor (GPCR)-associated pathways. Some of these membrane actions are initiated through transactivation of metabotropic glutamate receptors (mGluRs) (Boulware et al., 2005, 2007). Membrane-initiated estradiol signaling is an important component of estradiol action in the brain, as evidenced by its role in sexual receptivity, a classical estrogendependent behavior (Dewing et al., 2007), and by the synthesis of progesterone (Chaban et al., 2003; Micevych et al., 2007; Kuo et al., 2009b). Both membrane and estradiol-regulated nuclear signaling in the hypothalamus are dependent on $\mathrm{ER} \alpha$ (Micevych et

\footnotetext{
Received Feb. 27, 2010; revised July 23, 2010; accepted July 29, 2010.

This work was supported by National Institutes of Health Grant DA013185 (P.M.) and Training Grant HD07228 (R.D.).

Correspondence should be addressed to Dr. Paul Micevych, Department of Neurobiology, David Geffen School of Medicine at University of California, Los Angeles, Los Angeles, CA 90095-1763. E-mail: pmicevych@mednet. ucla.edu.

DOI:10.1523/JNEUROSCI.1038-10.2010

Copyright $\odot 2010$ the authors $\quad 0270-6474 / 10 / 3012589-08 \$ 15.00 / 0$
}

al., 2003; Wintermantel et al., 2006; Dewing et al., 2007; Kuo et al., 2009b).

While there is little doubt that membrane-initiated signaling is an important component of estradiol effects on brain function, questions persist about whether (1) intracellular ERs are intrinsic membrane proteins or receptors associated with the cell membrane; (2) full-length ER or alternatively spliced proteins (Friend et al., 1995; Poola et al., 2002; Li et al., 2003; Moriarty et al., 2006) are membrane ERs; and (3) estradiol regulates levels of its cognate receptor in the plasma membrane.

In general, membrane receptors are regulated in a number of complex ways, only one of which is through transcriptional regulation. More often, membrane receptor levels are regulated by trafficking, the insertion into and removal (internalization) from the cell surface (Sinchak and Micevych, 2003). Intracellular ER $\alpha$ levels are transcriptionally regulated by estradiol and the insertion of ER $\alpha$ into the plasma membrane appears to be estradiolregulated (Gorosito et al., 2008), but whether $\mathrm{ER} \alpha$ is internalized by estradiol has not been elucidated.

An effective way to study membrane receptor trafficking is with surface biotinylation. Membrane proteins are labeled when a portion of the molecule that is exposed to the extracellular space is linked to biotin. Western blots are then used to characterize the biotinylated protein. Cultured hypothalamic neurons were surface biotinylated to identify membrane $\mathrm{ER} \alpha$ and to determine whether the population of membrane ER $\alpha$ was stable, or whether estradiol regulated ER $\alpha$ levels in the plasma membrane. These studies demonstrate that in response to estradiol, full-length 66 $\mathrm{kDa} \mathrm{ER} \alpha$ and an alternatively spliced $52 \mathrm{kDa} \mathrm{ER} \alpha$ variant are rapidly and transiently trafficked at the cell surface. Consistent 
with the idea of an ER $\alpha$-mGluR1a signaling unit, mGluR1a was internalized in tandem with $\operatorname{ER} \alpha$. These findings suggest that estradiol regulates plasma membrane levels of its cognate receptor to modulate cellular response during long-term exposure to the steroid.

\section{Materials and Methods}

Animals. Animals were treated in accordance with the principles and procedures of the National Institutes of Health Guide for the Care and Use of Laboratory Animals. All experimental procedures were approved by the Chancellor's Animal Research Committee at the University of California, Los Angeles. Timed, pregnant Long-Evans female rats were purchased from Charles River. Wild-type C57BL/6 mice and ER $\alpha$ knock-out (ER $\alpha \mathrm{KO})$ mice were purchased from The Jackson Laboratory. Upon their arrival, animals were housed in a climate-controlled environment on a $12 \mathrm{~h}$ light/dark cycle and provided food and water ad libitum. To establish primary cultures or collect tissue, animals were removed from their home cage and anesthetized with isoflurane.

Primary hypothalamic cultures. Hypothalamic neurons were extracted from prenatal pups on embryonic day 18 (E18). Under sterile conditions, brains were removed and placed into chilled calcium- and magnesiumfree Hanks' balanced salt solution (HBSS-CMF). Using a stereoscope, the hypothalamus was dissected. Briefly, coronal sections were made rostral to the mammillary bodies and caudal to the optic chiasm. Each hypothalamus was isolated by removing extrahypothalamic tissue parasagittally along both lateral sulci and below the thalamus. Hypothalamic tissue was placed into chilled HBSS-CMF and enzymatically dissociated with $0.25 \%$ trypsin and $0.1 \%$ DNase for $10 \mathrm{~min}$ at $37^{\circ} \mathrm{C}$. Enzymatic dissociation was halted using 10\% charcoal-stripped fetal bovine serum in HBSS-CMF, and the samples were subsequently centrifuged at $800 \times g$ for $5 \mathrm{~min}$ at $4^{\circ} \mathrm{C}$, resuspended, and washed with chilled Neurobasal-A medium (NB). The dispersed tissue was mechanically dissociated with fire-polished Pasteur pipettes and cells passed through a $40 \mu \mathrm{m}$ cell strainer and plated onto poly-D-lysine $(0.1 \mathrm{mg} / \mathrm{ml})$-coated 6 -well culture dishes at a density of $\sim 1 \times 10^{6}$ cells $/ \mathrm{ml}$. Cultures were maintained in serum-free supplemented NB medium (B27, 2 mm glutamine, 1\% penicillin/streptomycin; Invitrogen) and kept in a constant environment of $37^{\circ} \mathrm{C}$ and $5 \% \mathrm{CO}_{2}$. A complete medium exchange was performed $1 \mathrm{~h}$ after plating and then a $50 \%$ exchange was done $24 \mathrm{~h}$ later and every fourth day while in culture. The day before experimentation, cells were switched to supplemented $\mathrm{NB}$ (insulin $10 \mathrm{mg} / \mathrm{ml}$, transferring $5.5 \mathrm{mg} / \mathrm{ml}$, selenium $5 \mu \mathrm{g} / \mathrm{ml}$, putrescine $100 \mu \mathrm{g} / \mathrm{ml}, 1 \%$ penicillin/streptomycin; Sigma). On the day of the experiment, culture medium was completely replaced with fresh NB medium $2-3$ h before experimental treatment. Estradiol (17 $\beta$-estradiol; Sigma) was solubilized in DMSO (vehicle) and prepared fresh in NB medium for each experiment.

Tissue. Hypothalamic tissue was taken from Long-Evans postnatal day 9 (PND9) rat pups or adult wild-type and $\mathrm{ER} \alpha \mathrm{KO}$ mice. Brains were removed from the cranium and hypothalamic tissue was isolated following the description above and placed into chilled HBSS-CMF. Uterine and ovarian tissue was extracted from timed, pregnant female LongEvans rats (E18) or taken from adult female mice. Uterine and ovarian tissue was identified, collected, and placed into chilled HBSS-CMF. Tissue was frozen and stored at $-80^{\circ} \mathrm{C}$ until used. Tissue was homogenized and lysed with a Kontes Dounce tissue grinder and radioimmunoprecipitation assay (RIPA) buffer (Triton X-100 1.25\%, SDS 0.1\%, 50 mm Tris$\mathrm{HCl}, 150 \mathrm{~mm} \mathrm{NaCl}, 5 \mathrm{~mm}$ EDTA, pH 7.6) supplemented with a mixture of protease and phosphatase inhibitors (HALT, Pierce). Cell lysate was collected and placed on ice for $20 \mathrm{~min}$, vortexed, and triturated 10 times with a pipette tip and then with a 26 gauge needle. The lysate was clarified by centrifugation at $14,000 \mathrm{rpm}$ for $5 \mathrm{~min}$ at $4^{\circ} \mathrm{C}$. The supernatant was collected and an aliquot was saved for BCA protein determination. Samples were prepared for Western blot analysis in Laemmli buffer plus 5\% $\beta$-mercaptoethanol.

Cell surface biotinylation. On day 10-14 in vitro, hypothalamic neurons were treated with $1 \mathrm{~nm}$ estradiol or vehicle in a constant environment of $37^{\circ} \mathrm{C}$ and $5 \% \mathrm{CO}_{2}$. At the end of estradiol treatment, cell culture dishes were placed on ice to prevent exocytosis and endocytosis.
Estradiol-containing NB medium was immediately aspirated and replaced with ice-cold PBS, $\mathrm{pH} 7.4$, supplemented with $1 \mathrm{mM} \mathrm{CaCl}_{2}$ and 1 $\mathrm{mM} \mathrm{MgSO}_{4}$ (PBS-CM). To label and isolate cell surface $\mathrm{ER} \alpha$ and mGluRla, the water-soluble, cleavable, and membrane-impermeable biotin analog sulfosuccinimidyl 2-(biotinamido)-ethyl-1,3-dithiopropionate (sulfo-NHS-SS-biotin; Pierce) was diluted in PBS-CM $(0.5 \mathrm{mg} / \mathrm{ml}, \mathrm{pH}$ 7.6) immediately before use and incubated with cells on ice for $20 \mathrm{~min}$ with occasional rocking. At the end of incubation, excess free sulfo-NHSSS-biotin was quenched with three incubations with $50 \mathrm{~mm} \mathrm{NH}_{4} \mathrm{Cl}$ and $50 \mathrm{~mm}$ glycine in PBS-CM. Quenching solution was aspirated and cells washed three times with ice-cold PBS-CM.

Internalization. On day 10-14 in vitro, hypothalamic neurons were placed on ice and NB medium was aspirated and replaced with ice-cold PBS-CM. To label cell surface ER $\alpha$ and mGluRla, sulfo-NHS-SS-biotin was diluted in PBS-CM $(0.5 \mathrm{mg} / \mathrm{ml}, \mathrm{pH} 7.6)$ immediately before use and incubated with cells on ice for $20 \mathrm{~min}$ with occasional rocking. At the end of incubation, excess free sulfo-NHS-SS-biotin biotin was quenched with three incubations with $50 \mathrm{~mm} \mathrm{NH}_{4} \mathrm{Cl}$ and $50 \mathrm{~mm}$ glycine in PBS-CM. The quenching solution was aspirated, cells washed three times with ice-cold PBS-CM, and then treated with $1 \mathrm{~nm}$ estradiol or vehicle for the indicated times in a constant environment $\left(37^{\circ} \mathrm{C}\right.$ and $\left.5 \% \mathrm{CO}_{2}\right)$. At the end of treatment, cells were placed on ice and the NB medium with estradiol was immediately aspirated and replaced with ice-cold PBS-CM. Cells were then incubated three times with membrane-impermeant reducing agent 2-mercaptoethanesulfonic acid (MESNA; Sigma), $100 \mathrm{~mm}$ in Tris buffer solution with $1 \mathrm{mM} \mathrm{CaCl}_{2}$ (TBS-C) ( $\mathrm{pH}$ 7.6) for $10 \mathrm{~min}$ to reduce the cell surface sulfo-NHS-SS-biotin. MESNA was oxidized with $50 \mathrm{~mm}$ iodoacetamide in PBS-CM ( $5 \mathrm{~min}$ ) and then the cells were washed three times with PBS-CM.

Cell lysis and isolation of biotinylated proteins. Cultured neurons were lysed with RIPA buffer supplemented with a mixture of protease and phosphatase inhibitors (HALT, Pierce). Cell lysate was collected and placed on ice for $20 \mathrm{~min}$, vortexed and triturated 10 times with a pipette tip followed by a 26 gauge needle. The lysate was clarified by centrifugation at $14,000 \mathrm{rpm}$ for $5 \mathrm{~min}$ at $4^{\circ} \mathrm{C}$. The supernatant, containing biotinylated and soluble cytoplasmic proteins, was collected. An aliquot of supernatant was saved for BCA protein determination and examination of cytoplasmic proteins by Western blot analysis. Biotinylated proteins were isolated by binding to NeutrAvidin beads (Pierce). All procedures were performed in Snap Cap spin columns (Pierce) for the remainder of the experiment. NeutrAvidin beads were prepared by washing two times with wash buffer $(0.5 \%$ Triton X-100, 0.1\% SDS, $50 \mathrm{~mm}$ Tris-HCl, 150 mм NaCl, 5 mм EDTA, pH 7.6, and supplemented with protease and phosphatase inhibitors). Supernatant containing biotinylated proteins was added to washed beads $(1: 1)$ and incubated overnight at $4^{\circ} \mathrm{C}$ with end-over-end rotation. The following day, beads were washed three times with wash buffer and once with Tris- $\mathrm{HCl}, \mathrm{pH} 7.5$, supplemented with protease and phosphatase inhibitors. Proteins labeled with the sulfo-NHS-SS-biotin were eluted from the beads with Laemmli buffer containing $50 \mathrm{~mm}$ DTT (1:1) for $5 \mathrm{~min}$ at $95-100^{\circ} \mathrm{C}$. The eluted proteins were separated from the NeutrAvidin beads by centrifugation and analyzed by Western blot.

Western blot analysis. For electrophoresis, samples were loaded onto $10 \%$ SDS polyacrylamide gels along with molecular weight protein standards (Cell Signaling Technology). Biotinylated protein fraction concentrations were equilibrated with Laemmli buffer containing 50 mм DTT according to BCA protein determination data gathered from cytoplasmic protein samples. For analysis of cytoplasmic proteins from rat hypothalamic, uterine, and ovarian tissue, $15 \mu \mathrm{g}$ of protein were loaded onto gels. The mouse hypothalamic and ovarian tissue used $50 \mu \mathrm{g}$ of protein loaded onto gels. For analysis of biotinylated proteins, a volume equivalent to 30 $\mu \mathrm{g}$ of cytoplasmic protein was loaded onto gels. Electrophoresis of proteins was performed with a MiniProtean Transblot (Bio-Rad) for $1 \mathrm{~h}$ at 0.03 constant-amps/gel. Gels were electroblotted onto Immobilon-p PVDF (Millipore) membrane using a chilled Hoefer transblotter (TE-42) for $1.5 \mathrm{~h}$ at 0.8 constant-amps. After transfer, gels were stained with Coomassie blue dye. Membranes were washed once with TBS plus $0.1 \%$ Tween 20 (TBS-T) (pH 7.5) and then nonspecific immunological binding sites were blocked with 5\% nonfat milk in TBS-T for 30 min on an 
A

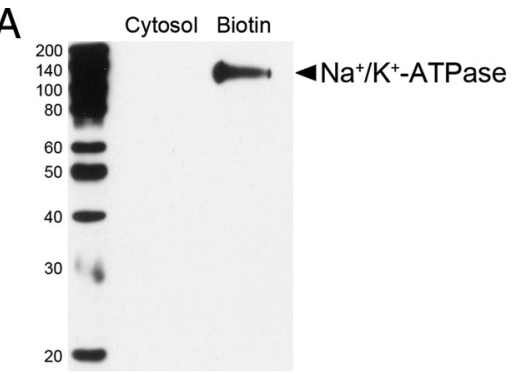

C

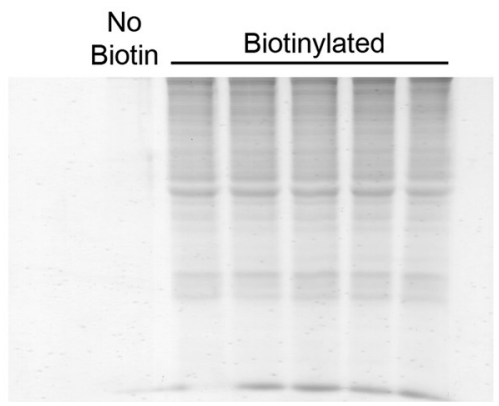

B

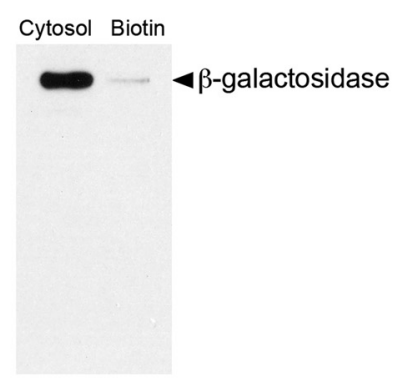

$\mathrm{D}$

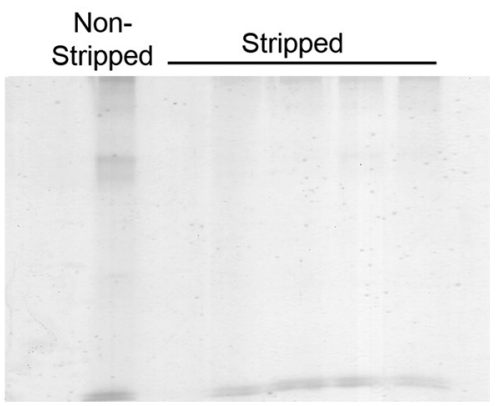

Figure 1. Cell surface biotinylation of hypothalamic neuronal cultures. $A, B$, Western blots were probed with $\mathrm{Na}^{+} / \mathrm{K}^{+}$-ATPase $(\boldsymbol{A})$ and $\beta$-galactosidase $(\boldsymbol{B})$ antibodies as controls to determine the purity of cytoplasmic (Cytosol) and biotinylated (Biotin) protein fractions, respectively. SDS polyacrylamide gels were stained with Coomassie blue after the protein transfer to examine biotinylation experimental controls and total protein loading of biotinylated samples. C, Gels were loaded with nonbiotinylated (No Biotin) and biotinylated samples from cell surface biotinylation experiments. D, Gels were loaded with non-MESNA-treated (Non-Stripped) and MESNA-treated (Stripped) protein samples from cell surface biotin internalization experiments.

cell surface proteins were labeled with the membrane-impermeable biotin, and that labeled protein fractions contained no cytoplasmic proteins, Western blot analysis of biotinylated (Fig. 1A) and cytoplasmic (Fig. $1 B)$ proteins was used to test for the presence of membrane and cytoplasmic markers. The biotinylated fraction (Fig. 1A) contained the membrane localized $\mathrm{Na}^{+}$/ $\mathrm{K}^{+}$-ATPase, but this protein was not detected in the cytoplasmic fraction (Fig. $1 B$ ). The cytoplasmic marker $\beta$-galactosidase was not found in the biotinylated fraction compared with the cytoplasmic fraction (Fig. $1 B$ ). The biotinylated fraction did contain a light $\beta$-galactosidase-immunoreactive band; however, this is likely due to a low level of membrane localized $\beta$-galactosidase (Aureli et al., 2009). These findings demonstrate that biotinylated fractions contain proteins that were localized to the plasma membrane and were not contaminated with cytoplasmic proteins.

To check for unspecific protein binding during surface biotinylation experiments, cells that were not labeled with biotin were processed along with biotinylated samples. Coomassie Blue stained SDS polyacrylamide gels revealed that nonbiotinylated

orbital shaker. Primary antibodies were diluted in 5\% nonfat milk in TBS-T and incubated overnight at $4^{\circ} \mathrm{C}$ on a side-to-side rocker. Membranes were washed three times with TBS-T and then with the secondary antibody also diluted in 5\% nonfat milk in TBS-T for $1 \mathrm{~h}$ on an orbital shaker. Membranes were then washed three times with TBS-T and once with TBS, pH 7.5. Immunoblots were visualized with autoradiography using enhanced chemiluminescence (ECL) (SuperSignal West Pico, Pierce).

Antibodies. ER $\alpha$ antibodies, MC-20 (1:1000) and H-184 (1:1000; both from Santa Cruz Biotechnology; MC-20 lot \# G2408 and B1709), directed against the $\mathrm{NH}_{2}$ - and $\mathrm{COOH}$-terminals, respectively, were used. Additionally, anti-mGluR1a (1:1000; Millipore), anti- $\beta$-actin $(1: 10,000$; Sigma), anti- $\mathrm{Na}^{+} / \mathrm{K}^{+}$-ATPase (1:5000; Millipore), and anti- $\beta$-galactosidase serum (1:5000; Millipore) were used. Light chain-specific secondary antibodies were peroxidase-labeled mouse anti-rabbit and goat anti-mouse IgG (Jackson ImmunoResearch Laboratories).

Densitometric analyses. To quantify protein levels, autoradiographic films were digitally scanned and analyzed. Band densities were analyzed using ImageJ software (version 1.41). Total band intensity values were calculated by subtracting the background for each film to account for any variation in background intensity across films. Data were then expressed as relative ratios, calculated as biotinylated values divided by cytoplasmic $\beta$-actin values obtained by Western blot analysis of the two protein fractions, and multiplied by 100 to obtain the percentage of protein ratio.

Statistical analysis. One-way ANOVA followed by a Tukey's post hoc test was used to determine statistical significance between experimental treatments. Data were analyzed using GraphPad Prism 4 software, and significance level was set at $p \leq 0.05$ for all experiments.

\section{Results}

\section{Cell surface biotinylation}

We surface biotinylated hypothalamic neurons with membraneimpermeable sulfo-NHS-SS-biotin using two different experimental protocols to investigate receptor trafficking (insertion and internalization) at the cell surface. Before these treatments, control experiments were conducted to ensure biotinylation efficiency of surface membrane proteins. To determine that only samples did not contain detectable levels of bound unspecific protein (Fig. 1C). Stained gels also revealed that biotinylated samples were equally loaded onto SDS polyacrylamide gels (Fig. 1C).

For internalization experiments, we tested whether surface biotinylated proteins would be internalized by estradiol stimulation. Neurons were surface biotinylated, stimulated and then treated with MESNA, a membrane-impermeable reducing agent, to strip away the sulfo-NHS-SS-biotin label from proteins on the cell surface. The presence of any remaining biotinylated proteins not reduced by MESNA indicated they were no longer on the cell surface and it was assumed they were internalized. To test the efficiency of biotin stripping, two controls were done: first, nonstripped controls detected the total amount of biotinylated protein on the plasma membrane (Fig. $1 D$ ); second, vehicle stimulated neurons did not contain biotinylated proteins, suggesting that MENSA effectively removed (first lane, Stripped) the biotin label from cell surface proteins (Fig. 1D).

To examine the specificity of the $\mathrm{ER} \alpha$ antibody MC-20, a series of controls were conducted in rat and mouse hypothalamic, uterine, and ovarian tissue. MC-20 is a polyclonal antibody directed toward amino acids on the $\mathrm{COOH}$-terminal (a.a. 579599) of mouse nuclear ER $\alpha$ protein (Clarke et al., 2000). Western blot analysis of the cytoplasmic proteins showed full-length 66 $\mathrm{kDa} \mathrm{ER} \alpha$ as well as several $\mathrm{ER} \alpha$-immunoreactive proteins (Fig. 2). In hypothalamic tissue, in addition to the $66 \mathrm{kDa} \mathrm{ER} \alpha$ band other ER $\alpha$-immunoreactive bands $(\sim 52,73,78,100,110$, and $125 \mathrm{kDa}$ ) were revealed before the detection of full-length ER $\alpha$ (Fig. 2A). In the uterus, while full-length $\mathrm{ER} \alpha$ was not seen using the MC-20 antibody, the ovary did contain $66 \mathrm{kDa} \mathrm{ER} \alpha$ as well as other $\mathrm{ER} \alpha$-immunoreactive proteins seen in hypothalamic tissue (Fig. $2 A$ ).

Surface biotinylation revealed several ER $\alpha$-immunoreactive proteins on the plasma membrane of hypothalamic neurons (Fig. $2 B)$. The primary immunoreactive protein identified with the 
MC-20 antibody migrated at $\sim 52 \mathrm{kDa}$ (Fig. 2B1). When Western blot autoradiographic films were exposed to ECLtreated immunoblots for $\sim 2 \mathrm{~h}$, full-length $66 \mathrm{kDa}$ ER $\alpha$ (Fig. 2 B2) was revealed along with other $\mathrm{ER} \alpha$-immunoreactive proteins $(\sim 46,78$, and $125 \mathrm{kDa})$. Biotin labeling of these proteins indicated they were present in the plasma membrane. Biotinylation of protein occurs when biotin covalently attaches to primary amines (e.g., lysine) present within the protein sequence, so membrane ER $\alpha$ labeled by membraneimpermeable biotin suggests that a portion of the receptor is exposed to the extracellular space. Although no transmembrane spanning domain has been described for ERs, the ligand-binding domain (E/F domain) has been predicted to insert into the plasma membrane due to hydrophobic amino acids (Kumar et al., 1986).

Western blot analysis of hypothalamic tissue from $\mathrm{ER} \alpha \mathrm{KO}$ mice suggests the 52 $\mathrm{kDa}$ protein is derived from the same gene (Esr1) as full-length $\mathrm{ER} \alpha$ (Fig. 2C). In wild-type mice, the $52 \mathrm{kDa}$ and $66 \mathrm{kDa}$ $\mathrm{ER} \alpha$ proteins are present in hypothalamic tissue, while in homozygous $\mathrm{ER} \alpha \mathrm{KO}\left(\mathrm{Esr}^{-/-}\right)$mice both proteins are absent. It is interesting to note that a small amount of $\mathrm{ER} \alpha$-immunoreactivity was detected in homozygous $\mathrm{ER} \alpha \mathrm{KO}$ mice, possibly representing other unidentified $\mathrm{ER} \alpha$ variants (Shao et al., 2007). Preabsorption of the MC-20 antibody with a peptide corresponding to the epitope against which the antibody was generated, a.a. 579-599 of ER $\alpha$, blocked staining of all the ER-immunoreactive bands (Fig. 2D). The presence of the 66 $\mathrm{kDa} \mathrm{ER} \alpha$ in hypothalamic, uterine, and ovarian tissue was verified using the $\mathrm{NH}_{2}$-terminally directed antibody $\mathrm{H}-184$ (epitope: $\mathrm{ER} \alpha$ a.a. 2-185; Fig. $2 E$ ). In contrast to MC-20 staining, H-184 also labeled various $\mathrm{ER} \alpha$-immunoreactive proteins but it did not detect the $52 \mathrm{kDa} E R \alpha$-immunoreactive protein (Fig. $2 E$ ).

\section{Estradiol stimulation increased the level of membrane ER $\alpha$ on the cell surface of hypothalamic neurons}

Western blot analysis of biotinylated proteins using MC-20 detected the expression of the major $\mathrm{ER} \alpha$-immunoreactive band at $52 \mathrm{kDa}$ and full-length $66 \mathrm{kDa} \mathrm{ER} \alpha$. We then tested how stimulation of these $\mathrm{ER} \alpha$ proteins changed their membrane levels. Estradiol (1 nM) stimulation rapidly increased the insertion of the $52 \mathrm{kDa}\left(\right.$ ANOVA $\left.F_{(4,30)}=3.025, p=0.033\right)$ and $66 \mathrm{kDa}$ (ANOVA $\left.F_{(4,15)}=3.27, p=0.041\right) \mathrm{ER} \alpha$ proteins in the plasma membrane of hypothalamic neurons (Fig. 3). Both ER $\alpha$ protein levels reached a significant level in the membrane after $30 \mathrm{~min}$ of estradiol treatment. The increase was transient and by $60 \mathrm{~min}$ of estradiol treatment, ER $\alpha$ protein levels were elevated but not significantly different from control levels (Fig. 3). Across the time points of the experiment, levels of both ER $\alpha$ proteins remained stable in the cytoplasmic protein fractions (data not shown), suggesting that changes in membrane levels were not directly due to transcriptional downregulation of $\mathrm{ER} \alpha$.

\section{Estradiol induces internalization of membrane ER $\alpha$}

In the second set of experiments, hypothalamic neurons were surface biotinylated and then treated with estradiol to determine whether membrane ER $\alpha$ was internalized. Estradiol (1 nM) rapidly increased the accumulation of biotinylated $52 \mathrm{kDa}$ (ANOVA $\left.F_{(4,25)}=8.581, p=0.0002\right)$ and $66 \mathrm{kDa}\left(\operatorname{ANOVA~}_{(4,15)}=4.287\right.$, $p=0.0164) \mathrm{ER} \alpha$ proteins in the cytoplasm, indicating that treatment with estradiol facilitated the removal of both $\mathrm{ER} \alpha$ variants from the cell surface (Fig. 4). Similar to the experiments that showed $\mathrm{ER} \alpha$ insertion into the membrane, the major $\mathrm{ER} \alpha$ immunoreactive band was at $52 \mathrm{kDa}$ and full-length $\mathrm{ER} \alpha$ at 66 $\mathrm{kDa}$ (Fig. 4). However, $52 \mathrm{kDa} \mathrm{ER} \alpha$ protein became internalized after $5 \mathrm{~min}$ of exposure to estradiol. In each case, levels of $52 \mathrm{kDa}$ and $66 \mathrm{kDa}$ ER $\alpha$ was significantly increased after $30 \mathrm{~min}$ of estradiol treatment but the time course of internalization extended longer than the insertion of the receptor. At 60-120 min, internalization of $52 \mathrm{kDa} \mathrm{ER} \alpha$ was still significantly greater than the basal level. This suggest that the two processes, insertion and internalization, are not coupled and may be regulated under different mechanisms.

\section{Estradiol stimulation of membrane ER $\alpha$-induced mGluR1a trafficking}

Membrane-initiated estradiol signaling in the hypothalamus and hippocampus has been shown to be dependent on an ER $\alpha$ transactivation of mGluR1a (Boulware et al., 2005; Dewing et al., 2007, 2008). To determine whether estradiol treatment changed the level of mGluRla protein in the plasma membrane, cell surface biotinylation was used. We could not demonstrate a significant estradiol-induced increase in membrane mGluRla levels ( $p=$ $0.1829)$. As with $\mathrm{ER} \alpha$, peak insertion ( $65 \%)$ occurred $30 \mathrm{~min}$ after hormone treatment (Fig. 5A). Interestingly, estradiol increased the level of biotinylated mGluR1a protein (internalization) in the cytoplasmic fraction (Fig. $5 B$ ), with the greatest level of internalization observed after 30-60 min of steroid treatment (ANOVA $\left.F_{(4,20)}=5.72, p=0.0031\right)$. This suggests that activating $\mathrm{ER} \alpha$ also induced mGluR1a internalization, an observation consistent with the $\mathrm{ER} \alpha$ transactivation of mGluRla. 


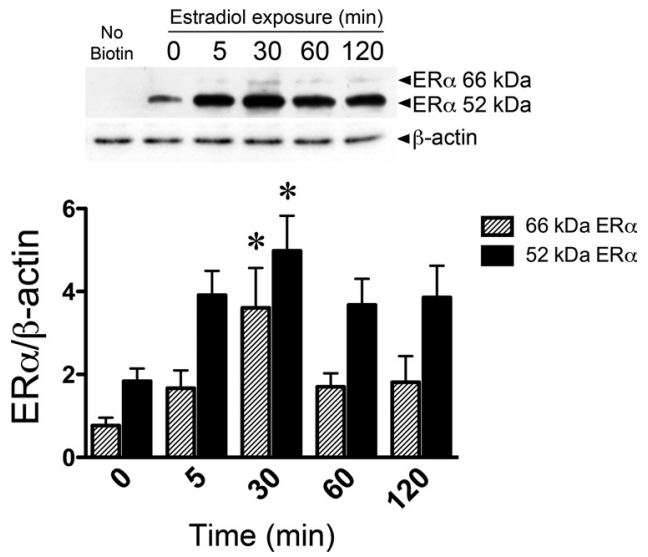

Figure 3. Estradiol stimulation of membrane $E R \alpha$ increased its insertion into the plasma membrane. Hypothalamic neuronal cultures were treated with $1 \mathrm{~nm}$ estradiol over time and surface biotinylated. Western blot analysis of surface biotinylated hypothalamic neurons using antibody MC-20 revealed the presence of $52 \mathrm{kDa}$ and $66 \mathrm{kDa} \mathrm{ER} \alpha$ (top). Control cultures were incubated without biotin (No Biotin) and processed similar to biotinylated samples. Equal loading of biotinylated samples was determined by probing cytoplasmic fraction blots with an $\beta$-actin antibody (bottom). The bar graph depicts that estradiol stimulation rapidly increased the amount of biotinylated $E R \alpha$ on the plasma membrane. A maximum of both $52 \mathrm{kDa}$ and 66 $\mathrm{kDa}$ ER $\alpha$ proteins was reached after $30 \mathrm{~min}$, after which concentrations returned toward basal levels (60-120 min). Bars (mean \pm SEM) represent the ratio of either $52 \mathrm{kDa}$ or $66 \mathrm{kDa}$ ER $\alpha$ immunoreactive band optical density value divided by the corresponding $\beta$-actin value and normalized (Tukey's post hoc, ${ }^{*} p<0.05 ; n=7$; time $=0$ vs $30 \mathrm{~min}$ ).
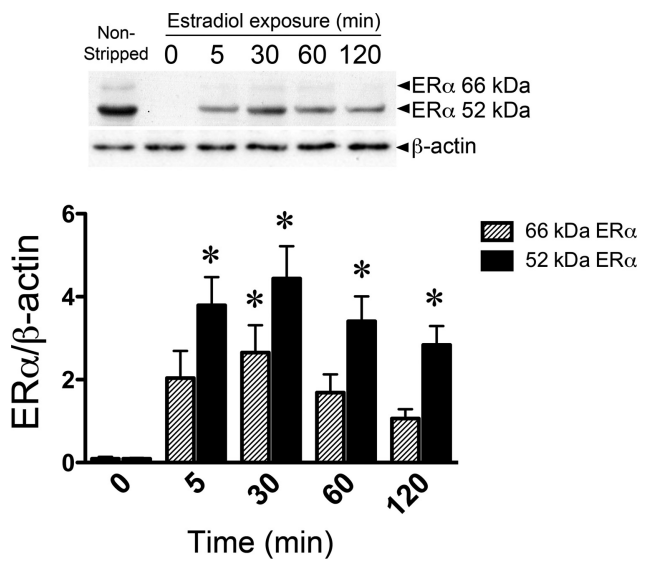

Figure 4. Stimulation of membrane $E R \alpha$ induced internalization of the receptor in hypothalamic neurons. Hypothalamic neuronal cultures were surface biotinylated and treated with $1 \mathrm{~nm}$ estradiol over time. Western blot analysis using antibody MC-20 revealed the presence of $52 \mathrm{kDa}$ and $66 \mathrm{kDa} E R \alpha$ (top). Cultures were incubated with membrane-impermeable MESNA to reduce and strip biotin away from cell surface proteins; control cultures were not stripped (NonStripped). Equal loading of biotinylated samples was determined by probing cytoplasmic fraction blots with a $\beta$-actin antibody (bottom). The bar graph shows that estradiol stimulation of $52 \mathrm{kDa}$ and $66 \mathrm{kDa}$ ER $\alpha$ resulted in the rapid (5 min) accumulation of the receptors in the cytoplasm, with a maximum at 30 min and remaining significant 60-120 min after steroid exposure. The bars (mean \pm SEM) represent the ratio of the $52 \mathrm{kDa}$ and $66 \mathrm{kDa}$ ER $\alpha$ immunoreactive band optical density value divided by the corresponding $\beta$-actin value and normalized (Tukey's post hoc, ${ }^{*} p<0.05 ; n=6$; time $=0$ vs 5, 30, 60, $120 \mathrm{~min}$ ).

\section{Discussion}

Estradiol is an extracellular messenger that activates membrane ERs to initiate cell signaling and activates intracellular ERs to directly modulate gene transcription. Because a number of molecules appear to bind estradiol, the identity of the ER(s) involved in membrane-initiated signaling remains unsettled. A preponderance of evidence, however, suggests that membrane ERs are products of the same genes as intracellular $\operatorname{ER} \alpha$ and $\operatorname{ER} \beta$
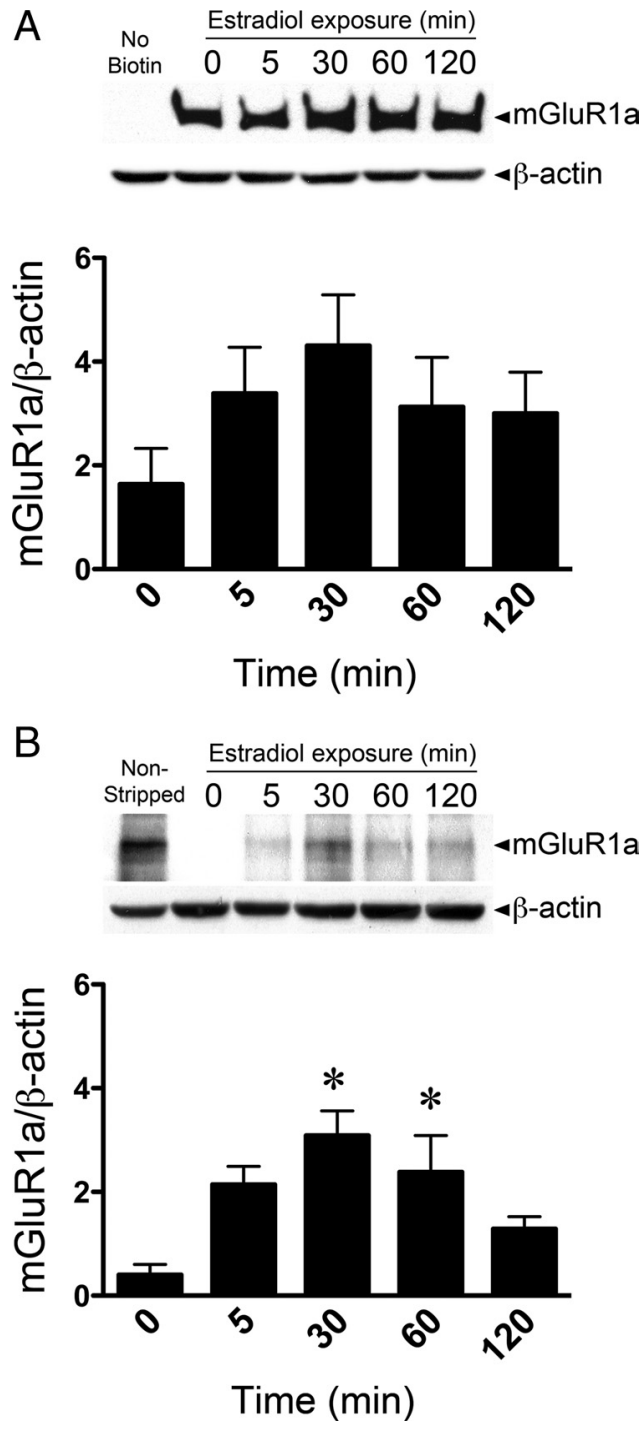

Figure 5. Activation of membrane ER $\alpha$ initiated the trafficking of mGluR1a on hypothalamic neuron plasma membranes. $A$, Hypothalamic neuronal cultures were treated with $1 \mathrm{~nm}$ estradiol for the times indicated ( $0-120 \mathrm{~min}$ ) and surfaced biotinylated. Western blot analysis $(A$, top) using an mGluR1a antibody revealed the presence of a $140 \mathrm{kDa}$ immunoreactive band on plasma membranes. Control cultures were incubated without biotin (№ Biotin) and processed similar to biotinylated samples. $\boldsymbol{B}$, Hypothalamic neuronal cultures were biotinylated and treated with $1 \mathrm{~nm}$ estradiol for the times indicated $(0-120 \mathrm{~min})$. Cultures were incubated with membrane-impermeable MESNA to reduce and strip biotin away from cell surface proteins; control cultures were not stripped (Non-Stripped). Western blot analysis ( $\boldsymbol{B}$, top) using an mGluR1a antibody revealed the rapid accumulation of the $140 \mathrm{kDa}$ protein in the cytoplasm with a maximum at $30-60 \mathrm{~min}$. Levels returned toward basal between 60 and $120 \mathrm{~min}$. Equal loading of biotinylated samples was determined by probing cytoplasmic fraction blots with a $\beta$-actin antibody ( $\boldsymbol{A}$ and $\boldsymbol{B}$, bottom). Bars (mean \pm SEM) represent the ratio of mGluR1aimmunoreactive band optical density value divided by the corresponding $\beta$-actin value and normalized (Tukey's post hoc, ${ }^{*} p<0.05 ; n=5$; time $=0$ vs $30,60 \mathrm{~min}$ ).

(Razandi et al., 1999). These ER proteins transduce membraneinitiated estradiol signaling events which affect cellular physiology and ultimately gene transcription (Micevych and Dominguez, 2009). Other endogenously expressed estradiol-binding proteins such as STX-binding protein or ER-X may also be involved, but whether they are products of $\mathrm{ER} \alpha$ or $\mathrm{ER} \beta$ genes is unknown (Razandi et al., 1999; Toran-Allerand et al., 2002; Revankar et al., 2005; Dominguez-Salazar et al., 2006; Qiu et al., 2008). In terms of female rodent sexual reproduction, $\mathrm{ER} \alpha$ in the hypothalamus is crit- 
ical (Moffatt et al., 1998; Kudwa and Rissman, 2003; Micevych et al., 2003; Wintermantel et al., 2006).

The present results demonstrate that $\mathrm{ER} \alpha$ is biotinylated on the surface of hypothalamic neurons. This supports various studies with membrane-impermeable estradiol constructs that indicate the presence of a cell surface ER (Mermelstein et al., 1996; Chaban et al., 2003; Qiu et al., 2003; Dewing et al., 2007). Moreover, the major immunoreactive membrane $\mathrm{ER} \alpha$ protein is not the full-length $66 \mathrm{kDa} \mathrm{ER} \alpha$ but rather the $52 \mathrm{kDa}$ protein. However, this may not be due to the difference between the levels of the 52 or $66 \mathrm{kDa} \mathrm{ER} \alpha$ but rather due to the affinity of MC-20 for these proteins. Similarly, a number of $\mathrm{ER} \alpha$-immunoreactive proteins have also been identified in mammary tissue (Bollig and Miksicek, 2000; Herynk and Fuqua, 2004).

Membrane $\operatorname{ER} \alpha$ and $\operatorname{ER} \beta$ interact with other membrane receptors to initiate signaling, including various growth factor and neurotransmitter receptors (Carrer and Cambiasso, 2002; Quesada and Etgen, 2002; Evinger and Levin, 2005; Micevych and Dominguez, 2009). Our laboratory has demonstrated that estradiol induction of female sexual receptivity is dependent on transactivation of mGluRla by activated $\operatorname{ER} \alpha$ (Dewing et al., 2007, 2008; Kuo et al., 2009a,b). In our present study, membrane ER $\alpha$ and mGluRla on hypothalamic neurons were rapid and transiently internalized within minutes of estradiol stimulation. The regulation of membrane $\mathrm{ER} \alpha$ and mGluRla protein levels by trafficking could serve as a method through which hypothalamic neurons regulate their response to estradiol, like other cell surface receptors.

As with other membrane receptors, ER levels are modulated by a series of complex processes that involve the control of expression and posttranscriptional modifications (Francesconi et al., 2009). Perhaps the most dramatic is the trafficking of receptors. Desensitization, a well documented process (Sinchak and Micevych, 2003), involves internalization of membrane receptors following agonist stimulation. Receptors are internalized during desensitization when endocytotic vesicles form and fuse with endosomes, where the ligand and receptor are uncoupled and sorted to be recycled or degraded.

A hallmark of insertion and internalization is the formation of pits on the plasma membrane. Estradiol treatment has been reported to induce pit formation on the membranes of hypothalamic neurons (Garcia-Segura et al., 1987; Olmos et al., 1987). Moreover, membrane $\mathrm{ER} \alpha$ is associated with caveolae, lipid rich microdomains that cluster intracellular signaling proteins (Luoma et al., 2008), and clathrin-coated vesicles (Moats and Ramirez, 2000; Sreeja and Thampan, 2004). Such pits may represent the fusion of exocytotic vesicles delivering $\mathrm{ER} \alpha$ to the membrane and endocytotic pits responsible for receptor internalization (Garcia-Segura et al., 1987; Olmos et al., 1987; Párducz et al., 1996; Moats and Ramirez, 1998).

Our present and previous results (Bondar et al., 2009) indicate an estradiol-mediated mechanism of insertion into the membrane. Localization of membrane $\operatorname{ER} \alpha$ requires palmitoylation and the association with caveolin proteins. Both are required for association with mGluRs and insertion into the plasma membrane (Razandi et al., 2002; Acconcia et al., 2005; Boulware et al., 2007; Luoma et al., 2008). One possibility is that estradiol may regulate the level of palmitoylation of $\mathrm{ER} \alpha$ and its association with caveolin. This idea is supported by the observation that estradiol treatment induced the rapid incorporation of ${ }^{3} \mathrm{H}$ palmitic acid into ER $\alpha$ protein (Acconcia et al., 2005). After $2 \mathrm{~h}$, estradiol decreased the interaction between $\mathrm{ER} \alpha$ and caveolin-1, a finding congruent with a decrease in membrane $\operatorname{ER} \alpha$ localiza- tion (Acconcia et al., 2005; Pedram et al., 2007). The time course of $\mathrm{ER} \alpha$ trafficking in the present experiments is very similar to the time course reported in previous studies, implying the events are linked.

Estradiol regulated the internalization of membrane $\mathrm{ER} \alpha$ in hypothalamic neurons. Membrane receptor internalization following agonist stimulation is regulated by $\beta$-arrestins and G-protein-coupled receptor kinases (GRKs). GRK phosphorylation desensitizes receptors and catalyzes their interaction with $\beta$-arrestins, which directs receptors toward endosomes (Marchese et al., 2008). Consistent with this idea, estradiol has been reported to rapidly activate GRK2 and recruit $\beta$-arrestin-1 to $\mathrm{ER} \alpha$ in cortical neurons (Dominguez et al., 2009). Internalization of activated membrane ER $\alpha$ has been suggested to be mediated by a $\beta$-arrestin mechanism.

An interesting parallel between membrane and intracellular ERs is the estradiol modulation of cognate receptors in different cellular compartments. Estradiol downregulates intracellular ER protein and mRNA levels (Lauber et al., 1990; Zhou et al., 1993; Alarid et al., 1999). In the present experiments, peak insertion into the membrane and internalization took place within an hour of estradiol treatment. This occurred without an observable change in $\mathrm{ER} \alpha$ levels in the cytoplasmic fraction. This suggests that our observations at the membrane are related to trafficking of $\operatorname{ER} \alpha$ and degradation rather than decreased synthesis of the protein. We expect, however, that long-term estradiol treatment may result in a decrease in transcription and decrease in total cellular ER levels as has been reported (Pinzone et al., 2004).

Studies in other cells have observed the movement of ERs to or from the plasma membrane. Similar to our experiments, a number of ER $\alpha$ variants were identified (Karthikeyan and Thampan, 1996; Stirone et al., 2003; Gorosito et al., 2008; Liu et al., 2008; Dominguez et al., 2009). Of particular interest were the studies of Gorosito et al. (2008), which used cell surface biotinylation of neurons to identify an ER $\alpha$-immunoreactive protein with an apparent molecular weight (MW) in the low $50 \mathrm{kDa}$ range. Similar to our results here and in astrocytes, vascular epithelial and endothelial cells have identified $\mathrm{ER} \alpha$ variants as the major membrane ER protein, where as the levels of the $66 \mathrm{kDa}$ protein are low and require a lengthy autoradiographic film exposure to detect full-length ER $\alpha$ (Li et al., 2003; Stirone et al., 2003; Bondar et al., 2009). The present study demonstrated that hypothalamic neurons, like other cell types, have a number of $\mathrm{ER} \alpha$ splice variants (Bollig and Miksicek, 2000; Li et al., 2003; Gorosito et al., 2008; Ishunina and Swaab, 2008; Dominguez et al., 2009).

Numerous ER $\alpha$ mRNA splice products have been identified in brain and other tissues (Friend et al., 1995; Bollig and Miksicek, 2000; Poola et al., 2002; Moriarty et al., 2006; Al-Bader et al., 2008). During alternative RNA splicing, exons are deleted or duplicated, resulting in a family of $\mathrm{ER} \alpha$ proteins (Herynk and Fuqua, 2004; Perlman et al., 2005). Such proteins have been identified using specific $\mathrm{NH}_{2}$ - and $\mathrm{COOH}$-terminal directed $\mathrm{ER} \alpha$ antibodies, but mass spectrometry studies (MALDI-TOF) have not detected these ER $\alpha$ variants in the membrane (Razandi et al., 2003; Heberden et al., 2006; G. Bondar and R. Dominguez, unpublished results). In the hypothalamus, splice variants have been suggested to participate in membrane-initiated estradiol signaling (Shughrue et al., 2002; Dominguez-Salazar et al., 2006). It is unclear what role splice variants play; however, studies report that the most common splice variant, $\operatorname{ER} \alpha \Delta 7$, which is missing the ligand-binding domain, is a dominant-negative protein (Couse et al., 1995; Bollig and Miksicek, 2000; Kos et al., 2002; Shughrue et al., 2002; Nethrapalli et al., 2005; Dominguez- 
Salazar et al., 2006). At present, it is difficult to ascertain which of the $\mathrm{ER} \alpha$-immunoreactive proteins identified in our experiments are the products of alternative splicing. The predominant membrane $\mathrm{ER} \alpha$-immunoreactive protein in our study migrates at $\sim 52 \mathrm{kDa}$, an MW similar to that of the ER $\alpha \Delta 7(52 \mathrm{kDa})$ and the $\mathrm{ER} \alpha \Delta 4(54 \mathrm{kDa})$, which have been identified in the brain (Fuqua et al., 1992; Bollig and Miksicek, 2000; Deecher et al., 2003; Perlman et al., 2005). Both ER $\alpha \Delta 7$ and $\mathrm{ER} \alpha \Delta 4$ express exon 1 and 2, however in our study H-184 did not detect proteins of either MW in hypothalamic tissue. Similar results have been reported in uterine, ovary, and cell lines (Deecher et al., 2003; Heberden et al., 2006; Shao et al., 2007). Currently, the identity of the $52 \mathrm{kDa} \mathrm{ER} \alpha$ remains unknown. In $\mathrm{ER} \alpha \mathrm{KO}$ astrocytes, both the 52 and the $66 \mathrm{kDa} \mathrm{ER} \alpha$ were not expressed, suggesting they are derived from the ER $\alpha$ gene (Bondar et al., 2009). Regardless of the identity of the $52 \mathrm{kDa} \mathrm{ER} \alpha$-immunoreactive protein, membrane-initiated estradiol signaling dependent on mGluR1a requires full-length $66 \mathrm{kDa} \mathrm{ER} \alpha$ (Boulware et al., 2005; Dewing et al., 2007, 2008). Thus, the function of the $52 \mathrm{kDa} \operatorname{ER} \alpha$ in the membrane is an open question.

Our findings that $\mathrm{ER} \alpha$ is present on the plasma membrane and that estradiol stimulation rapidly and transiently induced receptor trafficking suggest that membrane $\mathrm{ER} \alpha$ is rapidly regulated by its ligand, which may explain how membrane-initiated estradiol actions are self-limiting. Further studies are needed to elucidate the mechanism underlying these actions.

\section{References}

Acconcia F, Ascenzi P, Bocedi A, Spisni E, Tomasi V, Trentalance A, Visca P, Marino M (2005) Palmitoylation-dependent estrogen receptor alpha membrane localization: regulation by 17beta-estradiol. Mol Biol Cell $16: 231-237$.

Alarid ET, Bakopoulos N, Solodin N (1999) Proteasome-mediated proteolysis of estrogen receptor: a novel component in autologous downregulation. Mol Endocrinol 13:1522-1534.

Al-Bader MD, El-Abdallah AA, Redzic ZB (2008) Ontogenic profile of estrogen receptor alpha and beta mRNA and protein expression in fetal rat brain. Neurosci Lett 440:222-226.

Aureli M, Masilamani AP, Illuzzi G, Loberto N, Scandroglio F, Prinetti A, Chigorno V, Sonnino S (2009) Activity of plasma membrane betagalactosidase and beta-glucosidase. FEBS Lett 583:2469-2473.

Bollig A, Miksicek RJ (2000) An estrogen receptor-alpha splicing variant mediates both positive and negative effects on gene transcription. Mol Endocrinol 14:634-649.

Bondar G, Kuo J, Hamid N, Micevych P (2009) Estradiol-induced estrogen receptor-alpha trafficking. J Neurosci 29:15323-15330.

Boulware MI, Weick JP, Becklund BR, Kuo SP, Groth RD, Mermelstein PG (2005) Estradiol activates group I and II metabotropic glutamate receptor signaling, leading to opposing influences on cAMP response elementbinding protein. J Neurosci 25:5066-5078.

Boulware MI, Kordasiewicz H, Mermelstein PG (2007) Caveolin proteins are essential for distinct effects of membrane estrogen receptors in neurons. J Neurosci 27:9941-9950.

Carrer HF, Cambiasso MJ (2002) Sexual differentiation of the brain: genes, estrogen, and neurotrophic factors. Cell Mol Neurobiol 22:479-500.

Chaban VV, Mayer EA, Ennes HS, Micevych PE (2003) Estradiol inhibits atp-induced intracellular calcium concentration increase in dorsal root ganglia neurons. Neuroscience 118:941-948.

Clarke CH, Norfleet AM, Clarke MS, Watson CS, Cunningham KA, Thomas ML (2000) Perimembrane localization of the estrogen receptor alpha protein in neuronal processes of cultured hippocampal neurons. Neuroendocrinology 71:34-42.

Couse JF, Curtis SW, Washburn TF, Lindzey J, Golding TS, Lubahn DB, Smithies O, Korach KS (1995) Analysis of transcription and estrogen insensitivity in the female mouse after targeted disruption of the estrogen receptor gene. Mol Endocrinol 9:1441-1454.

Deecher DC, Swiggard P, Frail DE, O'Connor LT (2003) Characterization of a membrane-associated estrogen receptor in a rat hypothalamic cell line (D12). Endocrine 22:211-223.
Dewing P, Boulware MI, Sinchak K, Christensen A, Mermelstein PG, Micevych P (2007) Membrane estrogen receptor-alpha interactions with metabotropic glutamate receptor 1a modulate female sexual receptivity in rats. J Neurosci 27:9294-9300.

Dewing P, Christensen A, Bondar G, Micevych P (2008) Protein kinase C signaling in the hypothalamic arcuate nucleus regulates sexual receptivity in female rats. Endocrinology 149:5934-5942.

Dominguez R, Hu E, Zhou M, Baudry M (2009) 17beta-estradiol-mediated neuroprotection and ERK activation require a pertussis toxin-sensitive mechanism involving GRK2 and beta-arrestin-1. J Neurosci 29:42284238.

Dominguez-Salazar E, Shetty S, Rissman EF (2006) Rapid neural Fos responses to oestradiol in oestrogen receptor beta double knockout mice. J Neuroendocrinol 18:195-202.

Evinger AJ 3rd, Levin ER (2005) Requirements for estrogen receptor alpha membrane localization and function. Steroids 70:361-363.

Francesconi A, Kumari R, Zukin RS (2009) Regulation of group I metabotropic glutamate receptor trafficking and signaling by the caveolar/lipid raft pathway. J Neurosci 29:3590-3602.

Friend KE, Ang LW, Shupnik MA (1995) Estrogen regulates the expression of several different estrogen receptor mRNA isoforms in rat pituitary. Proc Natl Acad Sci U S A 92:4367-4371.

Fuqua SA, Fitzgerald SD, Allred DC, Elledge RM, Nawaz Z, McDonnell DP, O’Malley BW, Greene GL, McGuire WL (1992) Inhibition of estrogen receptor action by a naturally occurring variant in human breast tumors. Cancer Res 52:483-486.

Garcia-Segura LM, Olmos G, Tranque P, Naftolin F (1987) Rapid effects of gonadal steroids upon hypothalamic neuronal membrane ultrastructure. J Steroid Biochem 27:615-623.

Gorosito SV, Lorenzo AG, Cambiasso MJ (2008) Estrogen receptor alpha is expressed on the cell-surface of embryonic hypothalamic neurons. Neuroscience 154:1173-1177.

Heberden C, Reine F, Grosse B, Henry C, Zagar Y, Chaumaz G, Lieberherr M (2006) Detection of a raft-located estrogen receptor-like protein distinct from ER alpha. Int J Biochem Cell Biol 38:376-391.

Herynk MH, Fuqua SA (2004) Estrogen receptor mutations in human disease. Endocr Rev 25:869-898.

Ishunina TA, Swaab DF (2008) Estrogen receptor-alpha splice variants in the human brain. Gynecol Endocrinol 24:93-98.

Karthikeyan N, Thampan RV (1996) Plasma membrane is the primary site of localization of the nonactivated estrogen receptor in the goat uterus: hormone binding causes receptor internalization. Arch Biochem Biophys 325:47-57.

Kos M, Denger S, Reid G, Korach KS, Gannon F (2002) Down but not out? A novel protein isoform of the estrogen receptor alpha is expressed in the estrogen receptor alpha knockout mouse. J Mol Endocrinol 29:281-286.

Kudwa AE, Rissman EF (2003) Double oestrogen receptor alpha and beta knockout mice reveal differences in neural oestrogen-mediated progestin receptor induction and female sexual behaviour. J Neuroendocrinol 15:978-983.

Kumar V, Green S, Staub A, Chambon P (1986) Localisation of the oestradiol-binding and putative DNA-binding domains of the human oestrogen receptor. EMBO J 5:2231-2236.

Kuo J, Hariri OR, Micevych P (2009a) An interaction of oxytocin receptors with metabotropic glutamate receptors in hypothalamic astrocytes. J Neuroendocrinol 21:1001-1006.

Kuo J, Hariri OR, Bondar G, Ogi J, Micevych P (2009b) Membrane estrogen receptor-alpha interacts with metabotropic glutamate receptor type la to mobilize intracellular calcium in hypothalamic astrocytes. Endocrinology 150:1369-1376.

Lauber AH, Romano GJ, Mobbs CV, Pfaff DW (1990) Estradiol regulation of estrogen receptor messenger ribonucleic acid in rat mediobasal hypothalamus: an in situ hybridization study. J Neuroendocrinol 2:605-611.

Levin ER (2008) Rapid signaling by steroid receptors. Am J Physiol Regul Integr Comp Physiol 295:R1425-R1430.

Li L, Haynes MP, Bender JR (2003) Plasma membrane localization and function of the estrogen receptor alpha variant (ER46) in human endothelial cells. Proc Natl Acad Sci U S A 100:4807-4812.

Liu F, Day M, Muñiz LC, Bitran D, Arias R, Revilla-Sanchez R, Grauer S, Zhang G, Kelley C, Pulito V, Sung A, Mervis RF, Navarra R, Hirst WD, Reinhart PH, Marquis KL, Moss SJ, Pangalos MN, Brandon NJ (2008) 
Activation of estrogen receptor-beta regulates hippocampal synaptic plasticity and improves memory. Nat Neurosci 11:334-343.

Luoma JI, Boulware MI, Mermelstein PG (2008) Caveolin proteins and estrogen signaling in the brain. Mol Cell Endocrinol 290:8-13.

Marchese A, Paing MM, Temple BR, Trejo J (2008) G protein-coupled receptor sorting to endosomes and lysosomes. Annu Rev Pharmacol Toxicol 48:601-629.

Mermelstein PG, Becker JB, Surmeier DJ (1996) Estradiol reduces calcium currents in rat neostriatal neurons via a membrane receptor. J Neurosci 16:595-604.

Micevych P, Dominguez R (2009) Membrane estradiol signaling in the brain. Front Neuroendocrinol 30:315-327.

Micevych PE, Rissman EF, Gustafsson JA, Sinchak K (2003) Estrogen receptor-alpha is required for estrogen-induced mu-opioid receptor internalization. J Neurosci Res 71:802-810.

Micevych PE, Chaban V, Ogi J, Dewing P, Lu JK, Sinchak K (2007) Estradiol stimulates progesterone synthesis in hypothalamic astrocyte cultures. Endocrinology 148:782-789.

Moats RK 2nd, Ramirez VD (1998) Rapid uptake and binding of estradiol17beta-6-(O-carboxymethyl)oxime: ${ }^{125}$ I-labeled BSA by female rat liver. Biol Reprod 58:531-538.

Moats RK 2nd, Ramirez VD (2000) Electron microscopic visualization of membrane-mediated uptake and translocation of estrogen-BSA:colloidal gold by hep G2 cells. J Endocrinol 166:631-647.

Moffatt CA, Rissman EF, Shupnik MA, Blaustein JD (1998) Induction of progestin receptors by estradiol in the forebrain of estrogen receptoralpha gene-disrupted mice. J Neurosci 18:9556-9563.

Moriarty K, Kim KH, Bender JR (2006) Minireview: estrogen receptormediated rapid signaling. Endocrinology 147:5557-5563.

Nethrapalli IS, Tinnikov AA, Krishnan V, Lei CD, Toran-Allerand CD (2005) Estrogen activates mitogen-activated protein kinase in native, nontransfected CHO-K1, COS-7, and RAT2 fibroblast cell lines. Endocrinology 146:56-63.

Olmos G, Aguilera P, Tranque P, Naftolin F, Garcia-Segura LM (1987) Estrogen-induced synaptic remodelling in adult rat brain is accompanied by the reorganization of neuronal membranes. Brain Res 425:57-64.

Párducz A, Szilágyi T, Hoyk S, Naftolin F, Garcia-Segura LM (1996) Neuroplastic changes in the hypothalamic arcuate nucleus: the estradiol effect is accompanied by increased exoendocytotic activity of neuronal membranes. Cell Mol Neurobiol 16:259-269.

Pedram A, Razandi M, Sainson RC, Kim JK, Hughes CC, Levin ER (2007) A conserved mechanism for steroid receptor translocation to the plasma membrane. J Biol Chem 282:22278-22288.

Perlman WR, Matsumoto M, Beltaifa S, Hyde TM, Saunders RC, Webster MJ, Rubinow DR, Kleinman JE, Weickert CS (2005) Expression of estrogen receptor alpha exon-deleted mRNA variants in the human and nonhuman primate frontal cortex. Neuroscience 134:81-95.

Pinzone JJ, Stevenson H, Strobl JS, Berg PE (2004) Molecular and cellular determinants of estrogen receptor alpha expression. Mol Cell Biol 24:4605-4612.

Poola I, Abraham J, Baldwin K (2002) Identification of ten exon deleted ERbeta mRNAs in human ovary, breast, uterus and bone tissues: alternate splicing pattern of estrogen receptor beta mRNA is distinct from that of estrogen receptor alpha. FEBS Lett 516:133-138.
Qiu J, Bosch MA, Tobias SC, Grandy DK, Scanlan TS, Ronnekleiv OK, Kelly MJ (2003) Rapid signaling of estrogen in hypothalamic neurons involves a novel G-protein-coupled estrogen receptor that activates protein kinase C. J Neurosci 23:9529-9540.

Qiu J, Rønnekleiv OK, Kelly MJ (2008) Modulation of hypothalamic neuronal activity through a novel G-protein-coupled estrogen membrane receptor. Steroids 73:985-991.

Quesada A, Etgen AM (2002) Functional interactions between estrogen and insulin-like growth factor-I in the regulation of alpha $1 \mathrm{~B}$-adrenoceptors and female reproductive function. J Neurosci 22:2401-2408.

Razandi M, Pedram A, Greene GL, Levin ER (1999) Cell membrane and nuclear estrogen receptors (ERs) originate from a single transcript: studies of ERalpha and ERbeta expressed in Chinese hamster ovary cells. Mol Endocrinol 13:307-319.

Razandi M, Oh P, Pedram A, Schnitzer J, Levin ER (2002) ERs associate with and regulate the production of caveolin: implications for signaling and cellular actions. Mol Endocrinol 16:100-115.

Razandi M, Alton G, Pedram A, Ghonshani S, Webb P, Levin ER (2003) Identification of a structural determinant necessary for the localization and function of estrogen receptor alpha at the plasma membrane. Mol Cell Biol 23:1633-1646.

Revankar CM, Cimino DF, Sklar LA, Arterburn JB, Prossnitz ER (2005) A transmembrane intracellular estrogen receptor mediates rapid cell signaling. Science 307:1625-1630.

Shao R, Egecioglu E, Weijdegård B, Kopchick JJ, Fernandez-Rodriguez J, Andersson N, Billig H (2007) Dynamic regulation of estrogen receptoralpha isoform expression in the mouse fallopian tube: mechanistic insight into estrogen-dependent production and secretion of insulin-like growth factors. Am J Physiol Endocrinol Metab 293:E1430-1442.

Shughrue PJ, Askew GR, Dellovade TL, Merchenthaler I (2002) Estrogenbinding sites and their functional capacity in estrogen receptor double knockout mouse brain. Endocrinology 143:1643-1650.

Sinchak K, Micevych P (2003) Visualizing activation of opioid circuits by internalization of G protein-coupled receptors. Mol Neurobiol 27:197222.

Sreeja S, Thampan RV (2004) Estradiol-mediated internalisation of the nonactivated estrogen receptor from the goat uterine plasma membrane: identification of the proteins involved. Mol Cell Biochem 259:131-140.

Stirone C, Duckles SP, Krause DN (2003) Multiple forms of estrogen receptor-alpha in cerebral blood vessels: regulation by estrogen. Am J Physiol Endocrinol Metab 284:E184-192.

Toran-Allerand CD, Guan X, MacLusky NJ, Horvath TL, Diano S, Singh M, Connolly ES Jr, Nethrapalli IS, Tinnikov AA (2002) ER-X: a novel, plasma membrane-associated, putative estrogen receptor that is regulated during development and after ischemic brain injury. J Neurosci 22:8391-8401.

Wintermantel TM, Campbell RE, Porteous R, Bock D, Gröne HJ, Todman MG, Korach KS, Greiner E, Pérez CA, Schütz G, Herbison AE (2006) Definition of estrogen receptor pathway critical for estrogen positive feedback to gonadotropin-releasing hormone neurons and fertility. Neuron 52:271-280.

Zhou Y, Chorich LP, Mahesh VB, Ogle TF (1993) Regulation of estrogen receptor protein and messenger ribonucleic acid by estradiol and progesterone in rat uterus. J Steroid Biochem Mol Biol 46:687-698. 